\title{
分散制約最適化問題の
}

\section{異なる精度保証付き非厳密解法の統合手法 Integrating Different Incomplete DCOP Algorithms with Quality Bounds}

\author{
谷藤 拓麻
Takuma Yato

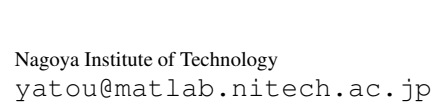

keywords: multi-agent, distributed constraint optimization problem

\begin{abstract}
Summary
Distributed Constraint Optimization Problem (DCOP) is a basic framework of cooperative problem solving in multi-agent systems. A number of distributed resource allocation problems including sensor networks, smart grids and disaster response tasks are formulated as DCOPs. Since DCOPs are generally NP-hard, incomplete algorithms are practical for large scale applications. DALO is an incomplete algorithm that guarantees the solution quality based on $\mathrm{k} / \mathrm{t}$-optimality. The k-optimality defines local optimality criterion based on the size of the group of deviating agents. On the other hand, the t-optimality is based on a group of surrounding agents within a fixed distance of a central agent. In the recent study, C-optimality has been introduced to generalize those criteria. The C-optimality defines criteria for local optimality in any arbitrary regions. As another type of optimality criteria, the p-optimality that is based on the induced width of pseudo-trees on constraint networks has been proposed. With p-optimality, the original problem is approximated by removing back edges of the pseudo-tree. Both types of incomplete algorithms have different week points. Since DALO is based on local optimality criteria, its solution quality depends on limited information (e.g. agent' $s$ values and constraints) within local regions. The solution quality of the p-optimal algorithms decreases when constraint graph consists of many cycles to be removed. In this paper, in order to achieve both lower computational complexity and better solution quality, we propose an integrated solution method based on both types of optimality criteria. Namely, we use information of the incomplete algorithm based on p-optimality and besides another method of C-optimality. Hence our aim is to employ complementary effects of both incomplete algorithms. Empirical results show that our integrated solution method obtain better solution quality than existing incomplete algorithms.
\end{abstract}

\section{1.はじめに}

複数の自律的に動作する要素である「エージェント」 が, 協調して問題を解決するマルチェージェントシステ ムは, 分散協調型のシステムのための主要な研究分野で ある . マルチェージェントシステムにおける協調問題解 決の基本的な枠組みとして, 分散制約最適化問題 (Distributed Constraint Optimization Problem , DCOP)[Modi 05, Petcu 05, Zhang 02] が研究されている.DCOPは, 変 数, 制約および評価関数が, 複数のエージェントに分散 して配置された最適化問題である .この問題の解法では， エージェント間のメッセージ通信を伴う, 分散協調アルゴ リズムが用いられる .センサ網 , スマートグリッド, レス キュー問題等の多くの分散資源割り当て問題が, DCOP として定式化されている [Zhang 05, Miller 12, Ramchurn
10] .

DCOP の解法は, 厳密解法と非厳密解法に分類される . 厳密解法は, 必ず最適解を求めることができる.しかし 一般に, 変数, 制約およひ評価関数の数についての問題の 規模や複杂隹さが増加すると, 計算量, 記憶量およびメッ セージサイズが指数的に増加するという問題点がある. これに対し，非厳密解法は，最適解を求めることができ るとは限らないが, 問題の規模に対する計算量, 記憶量 およびメッセージサイズは抑制される．弚のため，大規 模かつ複雑な問題に対しては非厳密解法が適用される.

非厳密解法として,$k / t$-optimality という解の最適性 の指標に基づく解法である DALO が提案された $[$ Kiekintveld 10] . $k$-optimality とは, エージェント数に基づく 解の最適性の指標である [Bowring 08] . $k$-optimal な解と は, $k$ 個のエージェントの変数値を変更しても利得の総和 
を向上できない解のことである .一方で, $t$-optimality と は，あるエージェントを中心に，一定範囲内にあるェー ジェント数に基づく解の最適性の指標である [Kiekintveld 10] . t-optimal な解とは, 制約網において, あるエージェ ントを中心に, $t$ ホップ内のエージェントの変数值を変 更しても利得の総和を向上できない解のことである . 近 年， $k / t$-optimality を一般化した $C$-optimality が提案さ れた [Vinyals 11] . また , $k$-optimality , $t$-optimality を組 み合わせた解の最適性の指標として $s$-optimality が提案 された [Vinyals 11] . s-optimal な解とは, エージェント 数が $s$ 個を超えない, 最大距離内にあるエージェントの 変数值を变更しても利得の総和を向上できない解のこと である。

$C$-optimality とは異なる視点に基づく解の最適性の指標 として,$p$-optimality か提案された [沖本 11] . p-optimality とは, 制約網に対応する擬似木の誘導幅に基づく解の最 適性の指標である.$p$-optimal な解とは, 元の問題から 木幅を $p$ に制限した問題に対する最適解のことである . $p$-optimalityにより，木幅を制限した問題の最適解を，元 の問題の近似解として用いる手法が提案された .

これらの非厳密解法には关れ尓れ異なる問題点がある． $C$-optimality に基づく解法によって得られる解品質は, 局 所情報のみに依存するため，解品質の向上か制限される . 一方で, $p$-optimality に基づく解法によって得られる解品 質は, 元の問題にサイクルが多く含まれる場合 , 大きく 低下する .

乥こで, 本研究では, 解品質の向上と計算量抑制の両立 を図るために ,これらの異なる解の最適性の指標に基づ く非厳密解法の統合を提案する.すなわち, $p$-optimality に基づく解法を実行することで得られた情報のもとで， $C$-optimality に基づく解法を実行することにより，両者 を相補的に用いることを目指す．また，実験により，提 案手法を既存の手法と比較し，关の有効性を評価する。

以下に本論文の構成を示す . 2 章では DCOP について 述べる. 3 章， 4 章では非厳密解法の解の最適性の指標に ついて述べる. 5 章では提案手法について述べる. 6 章で は実験による評価を示し，7 章ではまとめと今後の課題 について述べる。

\section{2. 分散制約最適化問題とその解法}

\section{$2 \cdot 1$ 分散制約最適化問題 (DCOP)}

分散制約最適化問題 (DCOP) は, 変数の集合 $X$, 制約 の集合 $\mathrm{C}$,評価関数の集合 $F$ ，およびェージェントの集 合から構成される. 各変数 $x_{i} \in X$ は, 離散有限集合 $D_{i}$ に含まれる变数值をとる. 変数は, 複数のエージェント に分散して配置される . 本論文では, 簡単のために , 一 つのエージェントに対して，一つの変数か配置されるも のとする . また, 必要に応じて変数と, 兴の変数か配置 されたエージェントを区別せずに扱う.$i$ 番目の変数 $x_{i}$

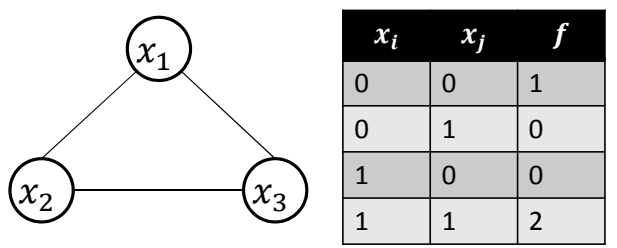

図 1 DCOP の例

がとる変数値を $d_{i}$ と表し, 制約 $c_{i, j}$ は, 変数 $x_{i}, x_{j}$ 間に 制約があることを表す．また， $c_{i, j}$ に対応する評価関数 を $f_{i, j}\left(x_{i}, x_{j}\right)$ と表す.ただし $, c_{i, j} \in \mathrm{C}, f_{i, j} \in F$ である 乥れ光れの変数への割り当て $A=\left[d_{1}, d_{2}, d_{3}, \ldots, d_{n}\right]$ に関 する評価関数の利得の総和は, 以下のように表される .

$R(A)=\sum_{f_{i, j} \in F} f_{i, j}$

$\mathrm{DCOP}$ の目的は, $R(A)$ を最大化するような割り当て $A^{*}$ を求めることである .

変数 $x_{i} \in X$ をノード，変数間にある制約 $c_{i, j} \in C$ を 辺として表現したグラフ (ネットワーク) $G=\langle X, C\rangle$ を制 約網という．この制約網において，各ノードは自身に関 連する制約を知っている．また，各ノードは，隣接してい るノードとのみ，通信することができる．図 1 に 3 つの ノード，3つの制約辺がある制約網の例を示す .この制約 網において, 評価関数の利得の総和の最大值は $R(A)=6$ であり，兴のときの割り当て $A=[1,1,1]$ が最適解 $A^{*}$ で ある

\section{$2 \cdot 2$ 分散制約最適化問題の解法}

分散制約最適化問題 (DCOP) の解法は, 厳密解法と非 厳密解法の二つに分類される。

厳密解法は，必ず最適解を求めることができる．厳 密解法として，制約網に対応する擬似木を利用したメ ッセージ交換により，最適解を求める DPOP[Petcu 05] , ADOPT[Modi 05] 等か提案されている.これらの解法は， 変数, 制約およひ評価関数の数が多くなり, 問題の規模 や複雑さが大きくなるにつれて, 計算量, 記憶量, メッ セージサイズ, メッセージ通信回数の幾つかか指数的に 増加するという問題点がある．したがって，大規模かつ 複杂隹な問題に対して, 厳密解法を適用することは困難で ある

非厳密解法は, 必ず最適解を求めることができるとは 限らないが, 比較的少ない計算量, メッセージ数および メッセージサイズで近似解を求めることができる．弚の ため, 大規模かつ複雑な問題には, 非厳密解法を適用す ることが実際的である.非厳密解法として, 局所的な山 登り法に基づくDSA[Zhang 02] 等が提案されている.

また, 非厳密解法の解品質について, 解の最適性の指標 が提案されている [Vinyals 11, Kiekintveld 10, Bowring 08 , 沖本 11] . 本研究では, $C$-optimality として一般化さ れている一連の指標 [Vinyals 11, Kiekintveld 10, Bowring 08] および p-optimality[沖本 11] に注目する . 


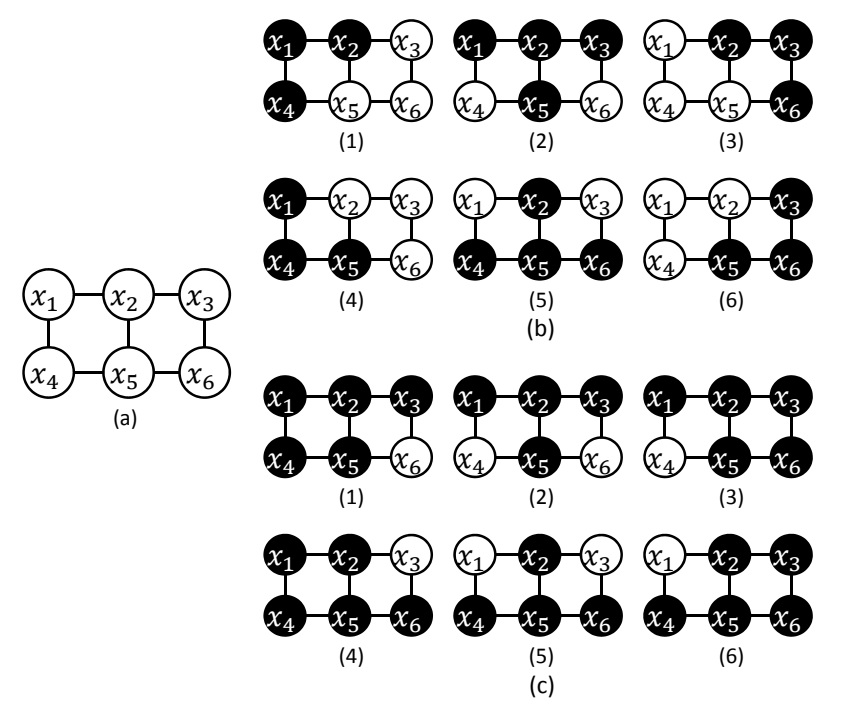

図 2 (a) は, DCOP の制約網である . (b) は $t=1$ の範囲 , (c) は $s=5$ の範囲である

\section{3. $C$-optimality}

$C$-optimality は, 分散制約最適化問題の解の最適性の 指標である.$C$ を $X$ の部分集合の多重集合とすると,$C-$ optimal な解とは，制約網において $C^{\alpha} \in C$ に含まれる ノードの変数值を変更しても, 利得の総和 $R(A)$ を向上 できない解のことである. $D\left(A, A^{\prime}\right)$ を異なる变数值を取 るノードの集合とすると， $C$-optimal な解 $A^{C}$ は，以下 のように定義される .

$$
\begin{aligned}
& \forall A^{\prime}, R\left(A^{C}\right)-R\left(A^{\prime}\right) \geq 0 \\
& \text { where } D\left(A^{C}, A^{\prime}\right) \subseteq C^{\alpha}, C^{\alpha} \in C
\end{aligned}
$$

ここで, 評価関数 $f_{i, j}$ に関係する変数 $x_{i}, x_{j}$ を完全に 含んでいるノードの部分集合 $C^{\alpha}$ の数を, $c c\left(f_{i, j}, C\right)=$ $\mid\left\{C^{\alpha} \in C\right.$ s.t. $\left.\left\{x_{i}, x_{j}\right\} \subseteq C^{\alpha}\right\} \mid$ とする.また, 評価関数 $f_{i, j}$ に関係する变数を含まないノードの部分集合 $C^{\alpha}$ の 数を, $n c\left(f_{i, j}, C\right)=\mid\left\{C^{\alpha} \in C\right.$ s.t. $\left.\left\{x_{i}, x_{j}\right\} \cap C^{\alpha}=\emptyset\right\} \mid$ と する.この時， $R\left(A^{C}\right)$ を $C$-optimal な解の利得の総和， $R\left(A^{*}\right)$ を最適解の利得の総和,$c c_{*}=\min _{f_{i, j} \in F} c c(F, C)$ ， $n c_{*}=\min _{f_{i, j} \in F} n c(F, C)$ とすると,$C$-optimal な解 $A^{C}$ の下界は, 以下のように計算される [Vinyals 11] .

$$
R\left(A^{C}\right) \geq \frac{c c_{*}}{|C|-n c_{*}} R\left(A^{*}\right)
$$

$C$-optimality は, $k / t$-optimality[Bowring 08 , Kiekintveld 10] と呼ばれる解の最適性を一般化した指標である.ま た， $k / t$-optimality を組み合わせた解の最適性の指標と して $s$-optimality が提案された [Vinyals 11]. 以降では, $t$-optimality， $s$-optimality について説明する.

\section{1 $t$-optimality}

$T\left(x_{i}, x_{j}\right)$ を $x_{i}, x_{j}$ 間のホップ数， $\Omega_{t}\left(x_{i}\right)$ を $x_{i}$ を中心 に，tホップ内にあるノードの集合と定義する $t$ - $t$-optimal な解とは， $\Omega_{t}\left(x_{i}\right)=\left\{u \mid T\left(u, x_{i}\right) \leq t\right\}$ となるノード $u$ の
変数值を変更しても, 利得の総和を向上できない解のこと である.すなわち , $t$-optimality は, $C=\left\{\Omega_{t}\left(x_{i}\right) \mid x_{i} \in X\right\}$ とした場合の解の最適性の指標である . 图 2(a) の制約網 において,$t=1$ の時に , 各ノードが作るノードの部分集 合 (グループ) を図 2(b) に示す . $x_{1}$ の場合, $x_{1}$ から, 1 ホップ内のノードは $\Omega_{1}\left(x_{1}\right)=\left\{x_{1}, x_{2}, x_{4}\right\}$ となる .ここ で, 全てのノード $x_{i}$ について,$x_{i}$ から, 1 ホップ内の ノードの集合 $\Omega_{1}\left(x_{i}\right)$ に含まれるノードの変数值を変更 しても，利得の総和を向上できない時， $t=1$-optimal な 解となる.

\section{$3 \cdot 2 s$-optimality}

$t_{s}\left(x_{i}\right)$ を $x_{i}$ を中心に，あるホップ内にあるノード数 が $s$ 個を超えない最大ホップ数，すなわち, $t_{s}\left(x_{i}\right)=$ $\max t$ s.t. $\left|\Omega_{t}\left(x_{i}\right)\right| \leq s$ と定義する.また， $\Phi_{s}\left(x_{i}\right)$ を $x_{i}$ から,$t_{s}\left(x_{i}\right)$ 内にあるノードの集合と定義する.$s$-optimal な解とは, $\Phi_{s}\left(x_{i}\right)=\Omega_{t_{s}\left(x_{i}\right)}\left(x_{i}\right)$ に含まれるノードの変数 值を变更しても，利得の総和を向上できない解のことで ある.すなわち, $s$-optimality は, $C=\left\{\Phi_{s}\left(x_{i}\right) \mid x_{i} \in X\right\}$ とした場合の解の最適性の指標である . 图 2(a) の制約網 において,$s=5$ の時に , 各ノードが作るノードの部分集 合 (グループ) を図 2(c) に示す . $x_{1}$ の場合,$\left|\Omega_{2}\left(x_{1}\right)\right| \leq 5$ であるため, $t_{5}\left(x_{1}\right)=2$ となる．したがって， $\Phi_{5}\left(x_{1}\right)=$ $\Omega_{2}\left(x_{i}\right)=\left\{x_{1}, x_{2}, x_{3}, x_{4}, x_{5}\right\}$ となる.ここで,全てのノー ド $x_{i}$ について,$x_{i}$ から,$t_{5}\left(x_{i}\right)$ ホップ内のノードの集 合 $\Phi_{5}\left(x_{i}\right)=\Omega_{t_{5}\left(x_{i}\right)}\left(x_{i}\right)$ に含まれるノードの変数值を変 更しても利得の総和を向上できない時, $s=5$-optimal な 解となる.

\subsection{DALO}

分散制約最適化問題の $k / t$-optimality に基づく非厳密解 法として DALO- $k / t$ カ提案された [Kiekintveld 10] .さら に ,s-optimality に基づく DALO- $s$ に拡張された [Vinyals 11] . この解法は, 大域的な同期を必要としない非同期ア ルゴリズムである . 各ノードの変数值は, ランダムな初 期值からはじまる. 弚して各グループが独立に，利得の 総和を最大化することを繰り返すことによって解を求め る, anytime 解法である.DALO は, 大きく 3 つのフェー ズから構成される。

(1) グループの生成: まず，はじめにグループを生成す る. 各ノードは, パラメータに応じて変数值と值域, 評価 関数の情報を互いに送受信しグループを生成する.ここ では, DALO- $t$ を例に説明する.各ノードは, 変数值と 值域を $t+1$ ホップ内, 自分に関係する評価関数を $t$ ホッ プ内にブロードキャストする .これにより，各ノードは， $t$ ホップ内のノードに関係する評価関数,$t+1$ ホップ内 のノードの変数值と值域を得る.ここで, $t+1$ 先のノー ドをフリンジと呼ぶ . 例えば, 图 $2(b)(1) \Omega_{1}\left(x_{1}\right)$ のフリ ンジは $\left\{x_{3}, x_{5}\right\}$ である

(2) グループ内の最適な割り当ての計算: 次に, 各ノー 


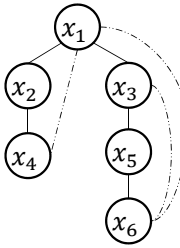

(a)

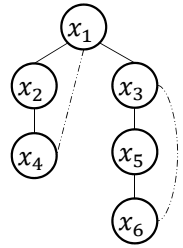

(b)
図 3 (a) は木幅が 3 の擬似木，(b) は (a) から生成した木幅を 2 に 制限した擬似木である

ドはフリンジの変数值を現在の值に固定し , 利得の総和 を最大化するように , グループ内の変数の最適な割り当 てを計算する . 最適な割り当ては，各ノードが，集めた 部分問題の情報により計算する .

(3) 割り当ての更新：現在の割り当てよりも，手順 (2) て計 算したグループ内の变数值の割り当てが, 利得の総和を大 きくするとき，割り当てを更新する .このために，各ノー ドは, 自身か計算した割り当てを,グループ内のノードに 送信する .ここで, 変数が重複する異なるグループが , 同 時に变数值を更新する競合を避けるために, lock/commit プロトコルを用いて ,グループ間の排他制御をする [Kiekintveld 10]. 各ノードは, 変数值を変更した時,$t+1$ ホッ プ内に変数值をブロードキャストし, 手順 (2) から反復 する . 全てのグループが, 現在の割り当てよりも , 利得 の総和を大きくできなくなったとき，解は収束する .

\section{$3 \cdot 4$ DALO の問題点}

この解法は, 各ノードがパラメータ $t / s$ によって決め られた範囲の局所情報を収集し，局所的な最適解を繰り 返し求める解法である。したがって，解品質は，局所情 報のみに依存し, 解品質の向上が制限されるという問題 点がある．また，解品質を向上させるために , パラメー 夕を大きくすると, 各ノードが解く問題の規模が大きく なり，計算コストが指数的に増加する可能性がある．

\section{4. $p$-optimality}

$p$-optimality は， $C$-optimality とは異なる視点に基づ く解の最適性の指標である . p-optimality では，制約網 に対応する擬似木を用いる . 图 3 の (a) に擬似木の例を 示す．擬似木は，制約網に含まれるノード間に順序関係 を与えるグラフ構造であり，制約網における生成木の一 つに対応する.生成木に含まれる辺を木辺，弚れ以外の 辺を後退辺と呼心゙。擬似木において，各ノードを根とす る部分木に含まれるノードのいずれかと，制約辺で関連 している上位ノード数を, 誘導幅 $w\left(x_{i}\right)$ と呼ぶ．また， 全ノードについて最大の誘導幅を，木幅 $W(G)$ と呼ぶ． ここで，与えられたパラメータ $p$ と，木幅が等しくなる まで後退辺を除去する .このようにして得られた擬似木 $G^{\prime}=\left\langle X, C^{\prime}\right\rangle$ の最適解を, $p$-optimal な解という.すなわ ち, $p$-optimality に基づく解法では，木幅をパラメータ $p$ によって制限した問題の最適解を，元の問題の近似解と
して用いる .

$f_{\text {max }}$ を評価関数の利得の最大値とすると, $p$-optimal な解 $A^{p}$ の下界は, 以下のように計算される [沖本 11] .

$$
R\left(A^{p}\right) \geq R\left(A^{*}\right)-f_{\max } \times \sum_{k=1}^{W(G)-p}(|X|-(k+1))
$$

\section{$4 \cdot 1 p$-optimal アルゴリズム}

$p$-optimality に基づく解法である,$p$-optimal アルゴリ ズム [沖本 11] は，大きく2つのフェーズから構成される . (1) 擬似木の木幅を $p$ に削減: フェーズ 1 では , 元の擬似 木 $G=\langle X, C\rangle$ から，与えられたパラメータ $p$ と，木幅が 等しくなるまで後退辺を除去する .この手順を Algorithm 1 に示す

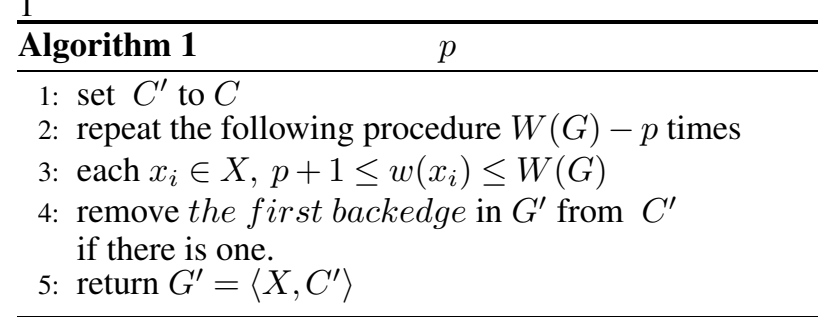

ここで first backedge とは, 各ノードにおいて ,一番上 位のノードと関連している後退辺のことをいう . 图 3 の (b) は, (a) の擬似木から後退辺を除去し，木幅を 2 に制 限した擬似木である。

(2) 木幅 $p$ の擬似木に厳密解法を適用：擬似木に基づく厳 密解法 [Petcu 05, Modi 05] により最適解を求める . この 解が $p$-optimal である.ここでは, 厳密解法 DPOP[Petcu 05]について概説する。

DPOP は動的計画法に基づく解法であり，擬似木の葉 ノードから順にボトムアップに利得を集計し，根ノード からトップダウンに変数值を決定する .このアルゴリズ ムは, 全ノードが一度に変数值を決定する, one-shot ア ルゴリズムである .ここで, 擬似木のノード $x_{i}$ に関連す るノードを次のように表す .

- $P\left(x_{i}\right):$ 辺で $x_{i}$ と関連する親ノード

- $P P\left(x_{i}\right)$ : 後退辺で $x_{i}$ と関連する祖先ノードの集合

- $C\left(x_{i}\right)$ : 木辺で $x_{i}$ と関連する子ノードの集合

- $P C\left(x_{i}\right)$ : 後退辺で関連する子孫ノードの集合

- $\overline{P P}\left(x_{i}\right): x_{i}$ を根とする部分木に含まれるいずれかの ノードと関連する $x_{i}$ の祖先ノード，および $P\left(x_{i}\right)$ か らなる集合

この解法は大きく2つのフェーズから構成される .

(1) UTIL メッセージの生成，伝搬：各ノード $x_{i}$ は， $\overline{P P}\left(x_{i}\right)$ に含まれるノードの全ての変数值の組について， 自身を根とする部分木の利得值の表 $U T I L_{x_{i}, P\left(x_{i}\right)}$ を $\mathrm{Al}-$ gorithm 2 の手続き (a) により計算する . この表は , UTIL メッセージとして $P\left(x_{i}\right)$ に送信される . 同樣な計算が根 ノードまでボトムアップに行われる.

(2) VALUE メッセージの生成, 伝搬: UTIL メッセージ が根ノードまで伝搬された後, 各ノード $x_{i}$ は最適な変数 
值 $d_{i}^{*}$ を Algorithm 2 の手続き (b) により決定する . この 値は, VALUE メッセージとして $C\left(x_{i}\right)$ に送信される . この計算は根から葉まで卜ップダウンに行われる

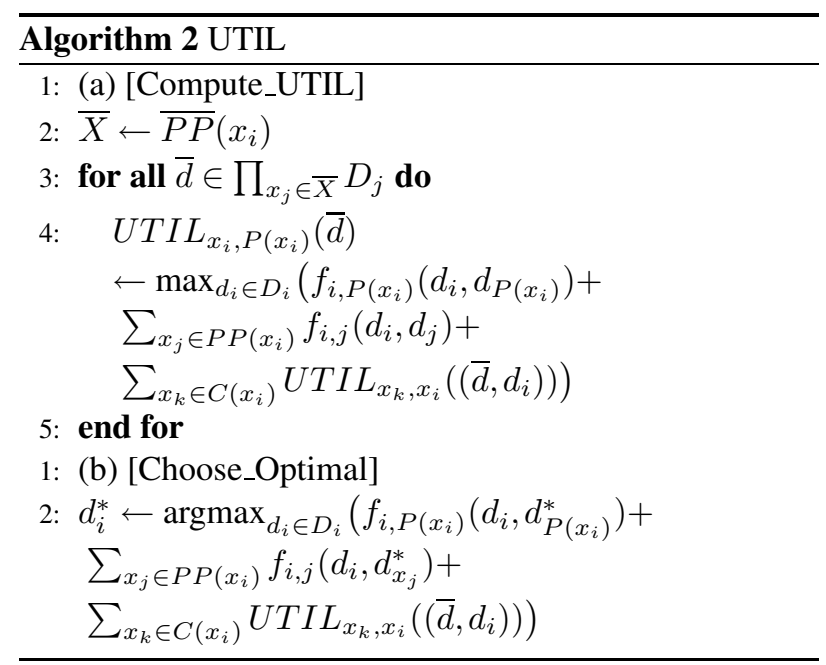

\section{$4 \cdot 2 p$-optimal アルゴリズムの問題点}

DPOP は擬似木の木幅について計算量 , メッセージサ イズが指数的に増加するという問題点がある. 光のため， $p$-optimality のように, 木幅を制限した問題の最適解を元 の問題の近似解として用いる手法が研究されてきた .し かし, $p$-optimality における解品質は除去される制約辺 に依存するため，制約網にサイクルが多く含まれるよう な問題では, 解品質が大きく低下する可能性がある .

\section{5. 提 案 手 法}

本章では, 解品質の向上と, 計算量の抑制の両立を 図るために，異なる解の最適性の指標 $p$-optimality， $C$ optimality に基づく非厳密解法の統合を提案する .

\section{$5 \cdot 1$ 提案手法の概要}

$p$-optimality に基づく解法は, サイクルが多く含まれ る問題の場合，解品質が大きく低下する．C-optimality に基づく解法は，局所情報のみに依存するため, 解品質 の向上が制限される . 乥こで, 解品質の向上を図るため に, p-optimality に基づく解法と $C$-optimality に基づく 解法を統合する.まず, 制約網に対応する擬似木を生成 し，炎の木幅をパラメータ $p$ に制限する．光して, DPOP の最初の処理である，UTIL メッセージを伝搬する .こ れにより，擬似木の根ノードは，大域的な利得の集計結 果を得る.しかし, 他ノードは, この恩恵を受けること がない，光こで, 同一の擬似木について, 各ノードを根 として，弚れ光れ UTIL メッセージを伝搬する．これに より，各ノードは，关れ光れのノードを根とした場合の， 自分を根とする部分木の利得の集計結果を得る .このよ うにして得られた利得の情報を, DALO の計算で用いる ことにより，各ノードにおいて，局所的かつ詳細な情報 と広範囲の情報を活用し, 解品質の向上を目指す．

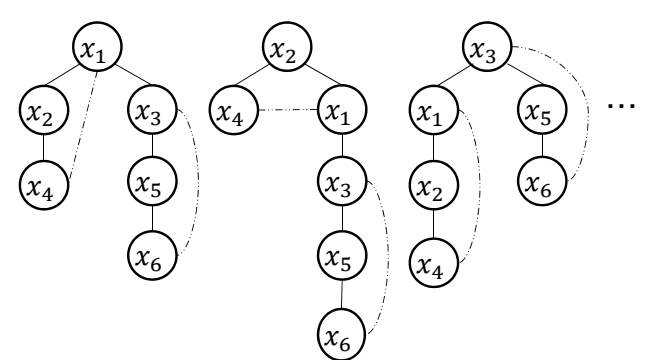

(a)

(b)

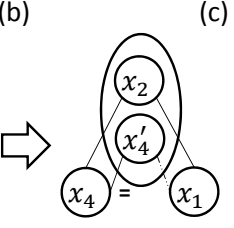

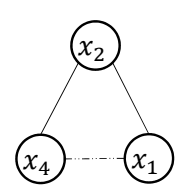

(b) (b')
図 4 同一の擬似木に対して, 各ノードを根として , UTIL メッセー ジを伝搬する.部分木間に後退辺がまたがる場合 , [Atlas 07] 類似する手法により (b)'のように変形する

提案手法のアルゴリズムは大きく二つのフェーズから構 成される .

- $p$-optimal 解法の実行

- $C$-optimal 解法の実行

\section{$5 \cdot 2 p$-optimal 解法の実行}

まず，制約網から深さ優先探索によって擬似木を生成 し , p-optimal アルゴリズムの手順 (1) と同樣の手続きに よって，木幅をパラメータ $p$ に制限する . 次に，同一の 擬似木に対して，光れ光れのノードを根として DPOPの UTIL メッセージを伝搬する．しかし，本来は根ではない ノードを，強引に根とすると矛盾が生じる．このような 例を図 4 に示す. 図4(b) のように， $x_{2}$ を根ノードとし た場合，部分木間に制約辺が存在する . 擬似木に基づく 解法は, 部分木間に制約辺がないことに基づく分割統治 法であるため，このままでは正しく計算ができない．光 こで，このような擬似木に対処する手法 [Atlas 07] と類 似する方法を用いる. 図 4(b) の, $x_{1}, x_{4}$ 間の制約辺を分 解する手順を示す. まず， $x_{4}$ の複製 $x_{4}^{\prime}$ を生成する. 谷 して，弚の複製を，部分木に分かれる部分のノード $x_{2}$ を 管理しているェージェントに配置する. として， $x_{1}, x_{4}$ 間にある制約 $c_{1,4}$ および評価関数 $f_{1,4}$ を削除し， $x_{1}, x_{4}^{\prime}$ 間に同一の制約 $c_{1,4^{\prime}}$ ，およひ評価関数 $f_{1,4^{\prime}}$ を追加する. また， $x_{4}, x_{4}^{\prime}$ 間に制約 $c_{4,4^{\prime}}$ ，等式評価関数 $f_{4,4^{\prime}}$ を追加 する .

この手続きを Algorithm 3 に示す . ノード $x_{i}$ に関連する ノードを以下のように表記する .

- $A N C\left(x_{i}\right): x_{i}$ の祖先ノードの集合

- $D E S\left(x_{i}\right): x_{i}$ の子孫ノードの集合

- $N\left(x_{i}\right): c_{i}$ の近傍ノードの集合

- $\operatorname{rep}\left(x_{i}\right): x_{i}$ の複製ノード

ここで, 変数の複製を持つエージェントは, 自身が元々管 理していたノードと，複製のノードとの組み合わせを評 


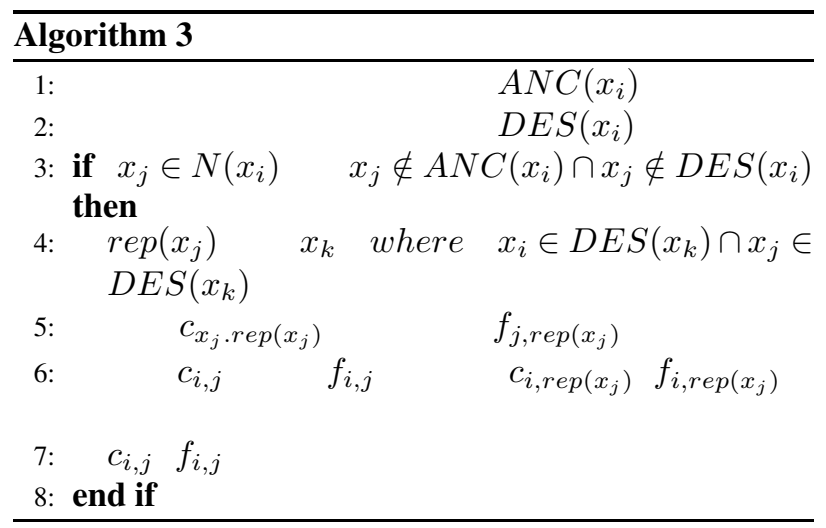

価する必要がある . エージェントが持つ複製ノードの集 合を $x_{r} \in \operatorname{cop}\left(x_{i}\right)$ とすると, Algorithm 4 のようにUTIL メッセージを生成する．従来のDPOP では，一つのノード Algorithm 4 変数の複製がある場合の UTIL メッセージ の生成

$$
\begin{aligned}
& \text { 1: }[\text { Compute_UTIL] } \\
& \text { 2: } \bar{X} \leftarrow \overline{P P}\left(x_{i}\right) \cup x_{i} \\
& \text { 3: for all } \bar{d} \in \prod_{x_{j} \in \bar{X}} D_{j} \text { do } \\
& \text { 4: } \quad \quad U T I L_{x_{r}, x_{i}} \\
& \quad \leftarrow \max _{d_{r} \in D_{r}}\left(\sum_{x_{k} \in C\left(x_{i}\right)} U T I L_{x_{k}, x_{i}}\left(\bar{d}, d_{r}\right)\right) \\
& \text { 5: end for } \\
& \text { 6: } \bar{X} \leftarrow \overline{P P}\left(x_{i}\right) \\
& \text { 7: for all } \bar{d} \in \prod_{x_{j} \in \bar{X}} D_{j} \text { do } \\
& \text { 8: } \quad U T I L_{x_{i}, P\left(x_{i}\right)}(\bar{d}) \\
& \quad \leftarrow \max _{d_{i} \in D_{i}}\left(f_{i, P\left(x_{i}\right)}\left(d_{i}, d_{p\left(x_{i}\right)}\right)+\right. \\
& \quad \sum_{x_{j} \in P P\left(x_{i}\right)} f_{i, j}\left(d_{i}, d_{j}\right)+ \\
& \left.\quad \sum_{x_{r} \in \operatorname{cop}\left(x_{i}\right)} U T I L_{x_{r}, x_{i}}\left(\left(\bar{d}, d_{i}\right)\right)\right) \\
& \text { 9: end for }
\end{aligned}
$$

のみを根とするので, 変数值を決定するために, VALUE メッセージを生成し，伝搬する必要がある . 提案手法で

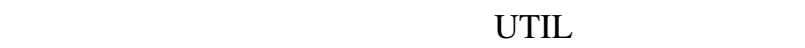
成するため，VALUE メッセージを伝搬することなく，各 ノードは大域的な利得に基づいて変数值を決定する.し かし, 各ノードの複数の变数值に対して, 利得が同一と なる対称解がある場合，ノード間におけるタイブレーク が必要となる. 乥こで, 各ノードに, 微小な乱数の值を 持つ単項関数を与えておく [A.Farinelli 08].これは, 各 ノードにおいて，対称解を確率的に除外することを意図 する .

\section{$5 \cdot 3 C$-optimal 解法の実行}

各ノードは, DALO と同樣に変数值と值域, 評価関数の 情報をブロードキャストするのに加えて, 前処理で生成し た UTIL メッセージもブロードキャストする .toptimality に基づいてグループを生成する場合, 評価関数の情報を $t$ ホップ内, 自身がとる変数值と值域を $t+1$ ホップ内にブ ロードキャストするのに加えて , 前処理で生成した UTIL メッセージも $t+1$ ホップ内にブロードキャストする.し たがって，各ノードは, グループのフリンジが生成した UTIL メッセージの情報を知ることができる .

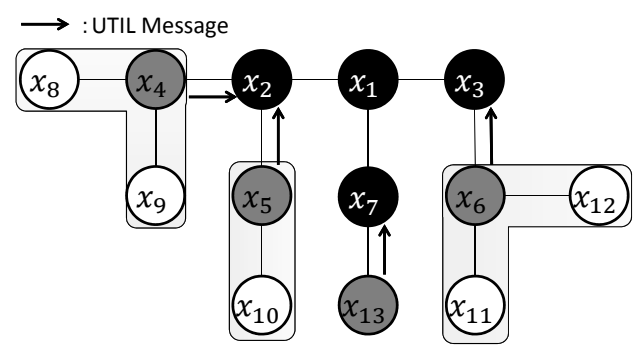

図 $5 C$-optimal 解法の実行 .フリンジが生成した UTIL メッセージ も利用して , グループ内ノードの最適な割り当てを計算する .

次に, グループ内の変数への最適な変数值の割り当て を計算する .この時, フリンジが生成した UTIL メッセー ジを利用する . 各グループ $C^{\alpha}$ について , グループ内の ノードが完全に関係している評価関数の集合を $T\left(C^{\alpha}\right)$, フリンジの集合を $f r i\left(C^{\alpha}\right)$ とすると，最適な割り当て $A^{\alpha}$ の計算は, 以下のようになる .

$$
\operatorname{argmax}_{A^{\alpha}}\left(\sum_{f_{i, j} \in T\left(C^{\alpha}\right)} f_{i, j}+\sum_{x_{i} \in f r i\left(C^{\alpha}\right)} U T I L_{x_{i}, P\left(x_{i}\right)}\right)
$$

ここでUTIL $L_{x_{i}, P\left(x_{i}\right)}$ は , 各グループの中心ノードを根 とした時に生成した UTIL メッセージである，例を図 5 に示す．ノード $x_{1}$ は， $T\left(C^{\alpha}\right)=\left\{f_{1,2}, f_{1,3}, f_{1,7}\right\}$ に加 えて, $\operatorname{fri}\left(C^{\alpha}\right)=\left\{x_{4}, x_{5}, x_{6}, x_{13}\right\}$ が光れ光れ生成した $U T I L_{x_{4}, x_{2}}, U T I L_{x_{5}, x_{2}}, U T I L_{x_{6}, x_{3}}, U T I L_{x_{13}, x_{7}}$ を用 いて，最適な割り当てを計算する。

最後に，計算した割り当てを更新するグループを決定 する.ここでは, DALO と同樣の手法を用いて, 割り当 てを更新するグループを決定する.変数值を変更したノー ドは, 現在の変数值を $t+1$ ホップ内にブロードキャス 卜する. 光して DALO と同樣に, 最適な割り当ての計算 と, 変数值の更新を反復する.

\section{4 提案手法の計算, 通信コスト}

まず提案手法における， $p$-optimal 解法の実行に必要な 通信, 計算コストについて考察する.p-optimal解法では, 擬似木の生成，木幅の制限，光して UTIL メッセージを伝 搬する . はじめに, 典型的な擬似木である DFS 木の生成 と，木幅を制限する時の通信コストについて考える．逐次 的な深さ優先探索を模倣する分散アルゴリズムは, 木辺 の数の 2 倍のサイクル数を要する.これをオーバヘッドの 上限と考えれば，木を生成する処理に必要なサイクル数 は, $2 \times$ (木辺の数) である.擬似木の木幅を制限するのに 必要なサイクル数は, Algorithm 1 より, $(W(G)-p) \times($ 木の最大深さ) となる $p=1$ とした時，木幅を制限する処 理は必要ない，次に，部分木間にまたがる制約辺の検知， 対処にかかる通信コストについて考える . ボトムアップ に子孫の集合，トップダウンに祖先の集合を集計するの に必要なサイクル数は, $($ 木の最大深さ $) \times 2$ となる .ノー ドの複製の設置にかかるサイクル数は , 最大で , $($ 木の最 
大深さ $)$ - (複製を置くノードの深さ) となる .

次に , DPOP の UTIL メッセージの伝搬にかかるサイ クル数と計算, 通信コストについて考察する. サイクル 数は, ボトムアップの計算を並行するため, 木の最大深 さだけ必要となる.各ノードが行う, UTIL メッセージの 計算量とメッセージサイズは，木幅と值域に対して，指 数的に増加する.提案手法では, 木幅を制限するため.計 算量，メッセージサイズを抑制できると考えられる．ま た，メッセージ数は，弚れ光れのノードを根とした場合 の UTIL メッセージを生成するため, 最大 (木辺) $\times($ ノ 一ド数) である. 产のため, 通信サイクル数の増加が原 因となり，実行時間が増加する。

次に，提案手法における $C$-optimal解法の実行にかかる 計算, 通信コストについて考察する.UTIL メッセージを フリンジから収集する処理は, 変数值を送信するメッセー ジと統合することができる.したがって,メッセージ数は DALO と比べて増加しない . この時, メッセージサイズは 増加するが, UTIL メッセージのサイズが小さければ，光 の増加は重大ではない，また，比較的大きなパケットサイ ズを用いる環境では, パケットに収まるメッセージならば サイズの差か隱蔽されることか期待できる.次に，局所範 囲の最適な割り当てを求める時にかかる計算コストを考 察する. DALO において, 各グループの解く問題の規模 (值域の直積のサイズ) は, $\left|\prod_{x_{i} \in C^{\alpha}} D_{i}\right|$ である.一方で， 提案手法では, フリンジの UTIL メッセージの值域の直 積のサイズを $\left|U T I L_{x_{i}, P\left(x_{i}\right)}\right|$ とすると, $\left|\prod_{x_{i} \in C^{\alpha}} D_{i}\right|+$ $\left|\prod_{x_{i} \in f r i\left(C^{\alpha}\right)}\right| U T I L_{x_{i}, P\left(x_{i}\right)}||$ となる.したがって, フリ ンジのノード数と, 兴の UTIL メッセージのサイズの分 だけ，計算コストが増加する．通信コストが計算コスト よりも大きい一般的な環境では, UTIL メッセージのサ イズが小さければ, 計算コストの増加の影響は, 相対的 に小さいと考えられる .

\section{5 提案手法による解の精度}

本節では，提案手法の解の下界を与える . 提案手法で は, $p$-optimal 解法を実行し, $C$-optimal 解法を実行する . ここで, 全ての $C^{\alpha} \in C$ に対して，割り当て $A^{\alpha}$ に含ま れる，ある変数への割り当てを $x_{i}^{\alpha}$ とする.また,$x_{i}^{p}$ を， $p$-optimal 解法の実行によって得られる割り当て, $x_{i}^{*}$ を， 最適な割り当てとする .この時, 上記の提案手法の実行 により, $x_{i}^{\alpha}=x_{i}^{p}$ if $x_{i}^{\alpha} \notin C, x_{i}^{\alpha}=x_{i}^{*}$ if $x_{i}^{\alpha} \in C$ となる . 提案手法の割り当て $A^{p c}$ は, 全ての $C^{\alpha} \in C$ に対して $R\left(A^{p c}\right) \geq R\left(A^{\alpha}\right)$ が成り立つ.したがって，

$R\left(A^{p c}\right) \geq \frac{\sum_{C^{\alpha} \in C} R\left(A^{\alpha}\right)}{|C|}$

ここで, $R\left(A^{\alpha}\right)=\sum_{f_{i, j} \in F} f_{i, j}\left(A^{\alpha}\right)$ である.各 $C^{\alpha}$ につ いて, 自身に関係する変数 $x_{i}, x_{j}$ が全て含まれている評 価関数 $f_{i, j}$ の集合 $T\left(C^{\alpha}\right)$, 部分的に含まれている評価関
数 $f_{i, j}$ の集合 $P\left(C^{\alpha}\right)$, 含まれてない評価関数 $f_{i, j}$ の集合 $N\left(C^{\alpha}\right)$ に分割すると,$R\left(A^{\alpha}\right)=\sum_{f_{i, j} \in T\left(C^{\alpha}\right)} f_{i, j}\left(A^{\alpha}\right)+$ $\sum_{f_{i, j} \in P\left(C^{\alpha}\right)} f_{i, j}\left(A^{\alpha}\right)+\sum_{f_{i, j} \in N\left(C^{\alpha}\right)} f_{i, j}\left(A^{\alpha}\right)$ となる. ここで, 評価関数の利得が負値でないとすると，

$$
R\left(A^{\alpha}\right) \geq \sum_{f_{i, j} \in T\left(C^{\alpha}\right)} f_{i, j}\left(A^{\alpha}\right)+\sum_{f_{i, j} \in N\left(C^{\alpha}\right)} f_{i, j}\left(A^{\alpha}\right)
$$

となる .

割り当て $A^{\alpha}$ は, $x_{i}^{\alpha}=x_{i}^{p}$ if $x_{i}^{\alpha} \notin C^{\alpha}, x_{i}^{\alpha}=x_{i}^{*}$ if $x_{i}^{\alpha} \in$ $C^{\alpha}$ なので，

$$
R\left(A^{\alpha}\right) \geq \sum_{f_{i, j} \in T\left(C^{\alpha}\right)} f_{i, j}\left(A^{*}\right)+\sum_{f_{i, j} \in N\left(C^{\alpha}\right)} f_{i, j}\left(A^{p}\right)
$$

(6)，(8)より,

$R\left(A^{p c}\right) \geq$

$\frac{\sum_{C^{\alpha} \in C} \sum_{f_{i, j} \in T\left(C^{\alpha}\right)} f_{i, j}\left(A^{*}\right)+\sum_{C^{\alpha} \in C} \sum_{f_{i, j} \in N\left(C^{\alpha}\right)} f_{i, j}\left(A^{p}\right)}{|C|}$

ここで, 光れ光れの評価関数 $f_{i, j}$ について, 光の評価関数 に関係する变数を含むグループ $C^{\alpha}$ の総数について考え る.(9)の各項は, 3 章で説明した $c c\left(f_{i, j}, C\right), n c\left(f_{i, j}, C\right)$ 用いて以下のように変形することができる．

$$
\begin{aligned}
& \sum_{C^{\alpha} \in C} \sum_{f_{i, j} \in T\left(C^{\alpha}\right)} f_{i, j}\left(A^{*}\right)=\sum_{f_{i, j} \in F} c c\left(f_{i, j}, C\right) \cdot f_{i, j}\left(A^{*}\right) \\
& \geq c c_{*} \sum_{f_{i, j} \in F} f_{i, j}\left(A^{*}\right)=c c_{*} \cdot R\left(A^{*}\right)
\end{aligned}
$$

$$
\begin{aligned}
& \sum_{C^{\alpha} \in C} \sum_{f_{i, j} \in N\left(C^{\alpha}\right)} f_{i, j}\left(A^{p}\right)=\sum_{f_{i, j} \in F} n c\left(f_{i, j}, C\right) \cdot f_{i, j}\left(A^{p}\right) \\
& \geq n c_{*} \sum_{f_{i, j} \in F} f_{i, j}\left(A^{p}\right)=n c_{*} \cdot R\left(A^{p}\right)
\end{aligned}
$$

そして, $p$-optimality の解の下界の式 (4)より, 以下のよ うに解の下界を与えることができる .

$R\left(A^{p c}\right) \geq$

$\frac{\left(c c_{*}+n c_{*}\right) R\left(A^{*}\right)-n c_{*} \cdot f_{\max } \times \sum_{k=1}^{W(G)-p}(|X|-(k+1))}{|C|}$

\section{6. 実 験と 評 価}

提案手法を実験により評価した . 


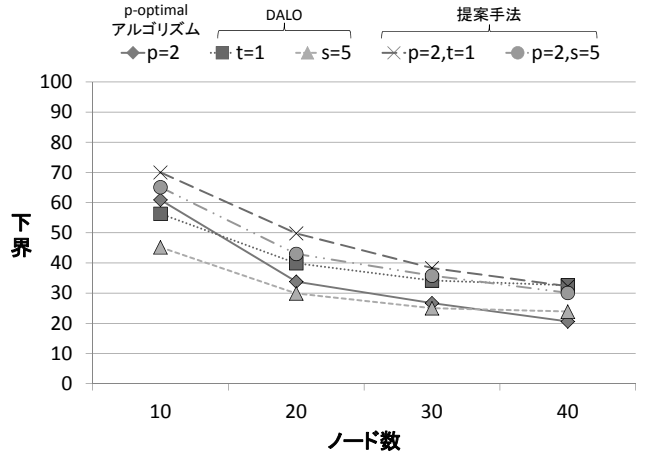

図 6 密度 3 のランダムグラフにおける各手法の下界值の比較

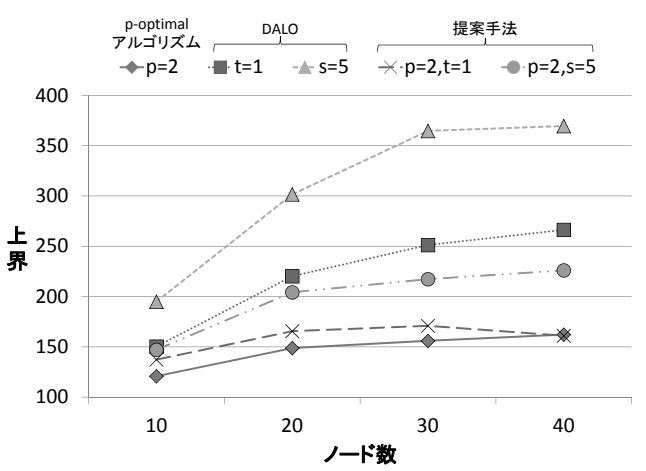

図 7 密度 3 のランダムグラフにおける各手法の上界値の比較

\section{1 実 験 の 設 定}

問題の制約網は, ランダムグラフと BA モデルに基づ いたスケールフリーグラフ [Barabasi 99] を用いた .生成 された制約網は，単一連結成分からなる．本章では，制 約の密度をノードにおける次数の平均と定義する. 各問 題のインスタンスは, ノード数, 密度を固定し, ランダ ムに生成した . 各変数の值域のサイズを 3 とし, 各評価 関数の利得は, 0 から 999 からランダムに選択した . 実 験結果は 30 インスタンスの平均值を示す .

\section{$6 \cdot 2$ 上界と下界}

まず, $p$-optimal アルゴリズム, DALO , 提案手法の关

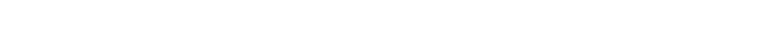

$p$-optimal アルゴリズムは, 事前に絶対誤差の上界 $E_{p}$ が得られる.式(4)より, $E_{p}=f_{\max } \times \sum_{k=1}^{W(G)-p}(|X|-$ $(k+1))$ とすると，下界は， $R(A)=R\left(A^{*}\right)-E_{p}$ であ る。また，上界は実際に得られる解をもとに， $R(A)=$ $R\left(A^{p}\right)+E_{p}$ とした .

DALO は, 事前に相対誤差の上界 $E_{c}$ が得られる .よっ て，式(3)より， $E_{c}=c c_{*} /\left(|C|-n c_{*}\right)$ とすると，下界は $R(A)=E_{c} R\left(A^{*}\right)$ である.また，上界は実際に得られる 解をもとに, $R(A)=R\left(A^{C}\right) / E_{c}$ とした.

提案手法も， $p$-optimal アルゴリズム，DALO と 同樣に事前に誤差の上界が得られる.式 (12) よ り, $E_{a b s}=n c_{*} \cdot f_{\max } \times \sum_{k=1}^{W(G)-p}(|X|-(k+1)) /|C|$, $E_{r e l}=\left(c c_{*}+n c_{*}\right) /|C|$ とすると，下界は， $R(A)=$ $E_{r e l} R\left(A^{*}\right)-E_{a b s}$ である。また，上界は実際に得られ
る解をもとに， $R(A)=\left(R\left(A^{p c}\right)+E_{a b s}\right) / E_{r e}$ とした. 図 6 と図 7 は, 密度 3 の異なるノード数 (変数)のグラ フにおける下界, 上界の比較を示す．弚れ光れの值は最 適解に対して正規化されている．下界，上界ともに，100 に近いほど良い結果となる.图 6 より, p-optimal アル ゴリズムは, ノード数 10 では, DALO よりも高い下界 值が得られることが分かった . また , ノード数の増加に 対して，下界值の低下が大きいことが分かった .一方で， DALO は, ノード数の増加に対して下界值の低下は小さ く,ノード数 40 では, $p$-optimal アルゴリズムよりも高い 下界值が得られることが分かった . 提案手法は, 既存の手 法よりも高い下界值が得られており，従来手法の下界を 相補的に改善する傾向があることが分かった．図 7 より， $p$-optimal アルゴリズムは, どの手法よりも良い上界が得 られることが分かった . 提案手法の上界は, $p$-optimal ア ルゴリズム, DALO の中間の值となる傾向があることが 分かった。

\section{$6 \cdot 3$ 解 品 質}

提案手法の解品質を既存の手法である $p$-optimal アル ゴリズム, DALO と比較した . 実験では, $p$-optimal ア ルゴリズム， DALO- $t$ 及び DALO- $s$, 光して $p$ と， $t$ お よび $s$ を組み合わせた提案手法を比較した . また，解品 質とは，最適解に対して正規化された值を表す．

図 8 から図 11 に 40 ノード (変数) からなる異なる密 度のグラフにおける各手法の比較を示す . グラフは , 左 から $p$-optimal アルゴリズム, DALO , 提案手法となって いる.ここでDALO と提案手法は, 収束時の解品質であ る。また，DALO および提案手法に用いる指標は，図 8 と図 9 は, $t$-optimality, 図 10 と図 11 は, $s$-optimality となっている.また, 図 8 , 图 9 の密度 5 と 7 の結果に おいて , $t=2$ とした , DALO および提案手法の $t$-optimal 解法は, 各ノードの問題の規模の増加により結果を得ら れなかった . 実験の結果，提案手法によって得られる解 品質は, どちらのグラフ構造においても既存の手法より も高品質であることが分かった . また，どの手法も密度 が上がるにつれて解品質が低下することが分かった . 特 に,p-optimal アルゴリズムでは光の傾向か顕著であり， これは除去される制約辺が多くなるためである。提案手 法は, $p$-optimal 解法と $C$-optimal 解法を組み合わせてい るため, 密度の上昇に対して, 解品質の低下は DALO と 同程度に抑えられている。

次に,全ノードが最初に変数值を変更したとき，すなわ ち, one-shot 時の $p$-optimal アルゴリズム, 乥してDALO$t, p$ と $t$ を組みわせた提案手法を比較した .ここで, 提 案手法における one-shot 時とは, $C$-optimal 解法を実行 時に, 最初に全ノードが変数值を変更したときである． ノード数 40 のランダムグラフにおける, one-shot 時の 解品質の比較を図 12 に示す. 実験の結果，密度 3 では， DALO- $t$ よりも , $p$-optimal アルゴリズムのほうが, 高品 


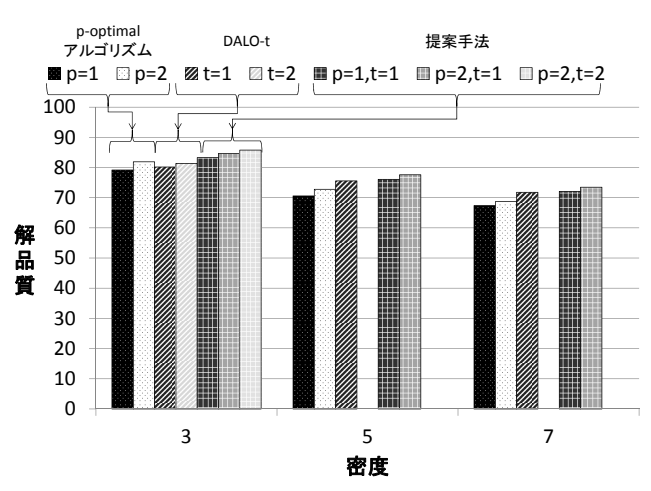

図 8 ノード数 40 のランダムグラフにおける各手法 の解品質の比較

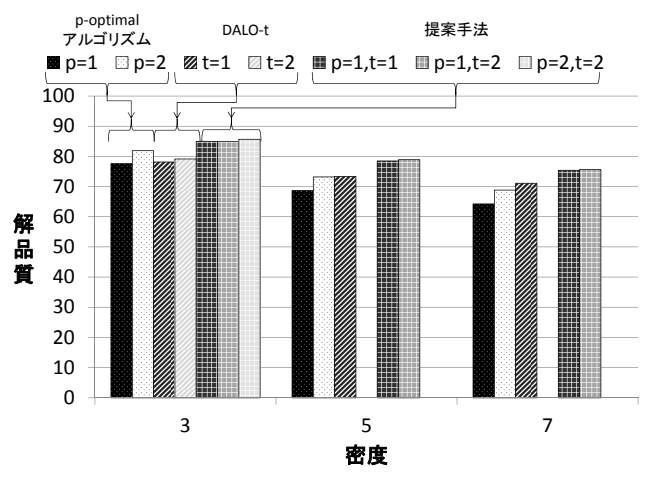

図 9 ノード数 40 のスケールフリーグラフにおける 各手法の解品質の比較

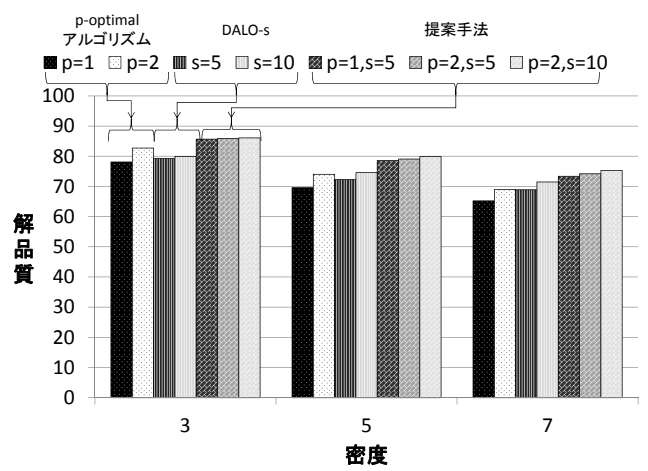

図 10 ノード数 40 のランダムグラフにおける各手法 の解品質の比較

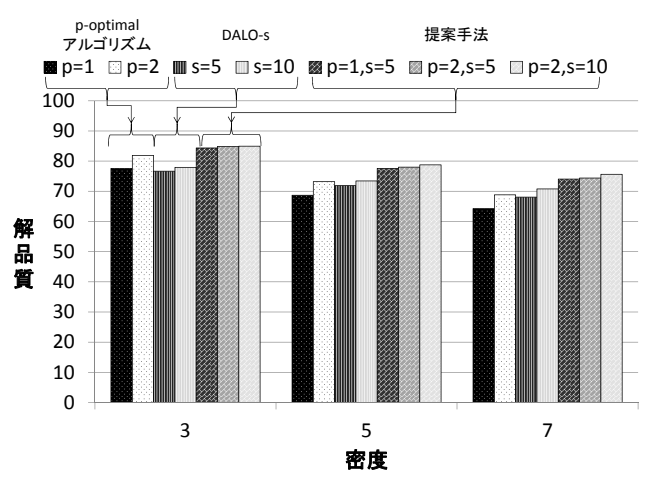

図 11 ノード数 40 のスケールフリーグラフにおける 各手法の解品質の比較

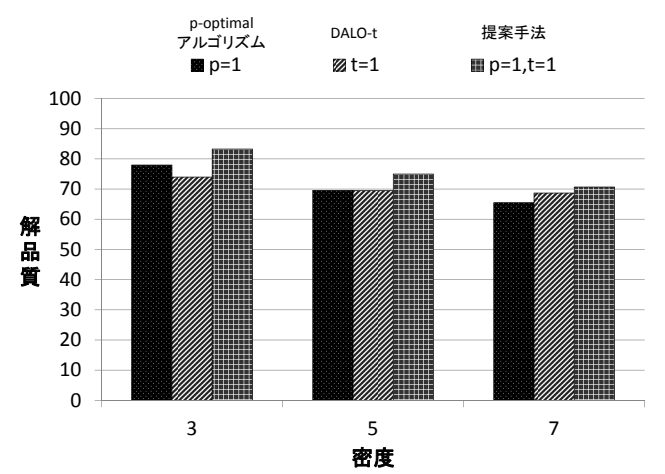

図 12 ノード数 40 のランダムグラフにおける one-shot 時の各手法 の解品質の比較

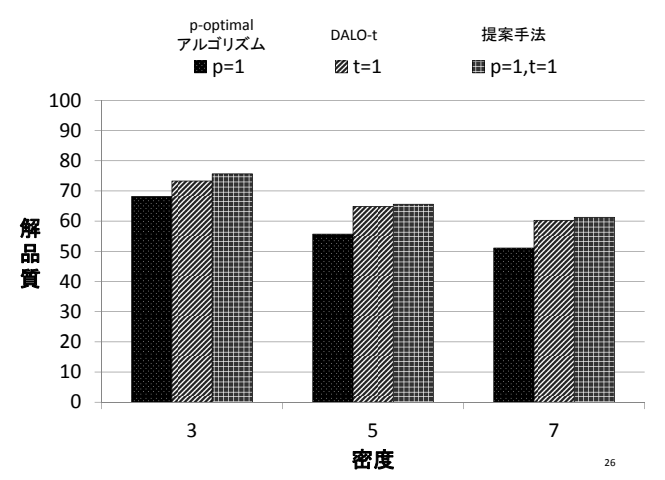

図 13 評価関数の利得が 0,1 の頂点彩色問題に対し て , ノード数 100 のランダムグラフにおける 各手法の解品質の比較

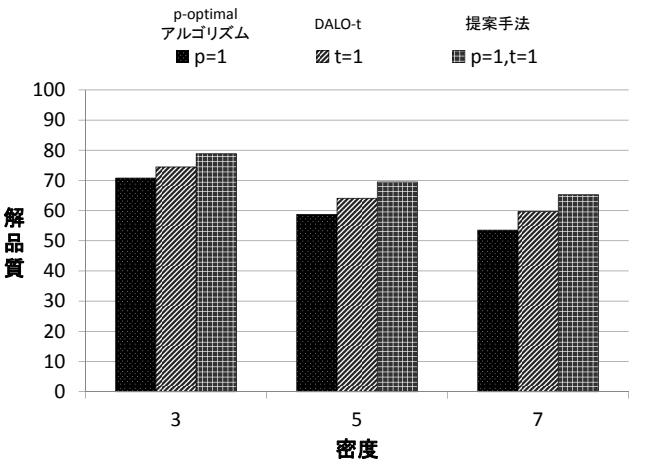

図 14 評価関数の利得が $0,1 \sim 9$ の頂点彩色問題に 対して,ノード数 100 のランダムグラフにお ける各手法の解品質の比較

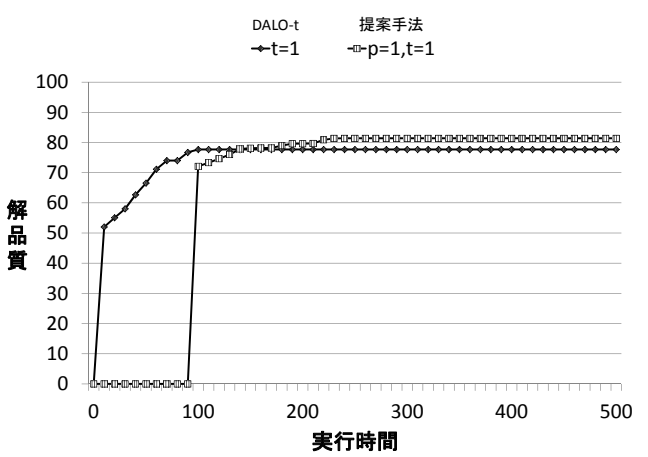

図 15 ノード数 50 , 密度 4 のランダムグラフにおけ る提案手法と DALO- $t$ の収束速度の比較 
質な解が得られることが分かった .これは, DALO は利 得の改善を繰り返す anytime アルゴリズムであるため， one-shot 時では, 十分な解品質が得られていないからで ある.また，提案手法は，one-shot 時においても，既存 の手法よりも高品質な解が得られることが分かった . 提 案手法も DALO と同樣に, anytime アルゴリズムである が, 前処理として, $p$-optimal 解法の実行により, 解が得 られているため, 既存の手法よりも高品質な解が得られ たと考えられる .

続いて頂点彩色問題に対して,$(p=1, t=1)$ とした提案 手法と $p=1$ とした $p$-optimal アルゴリズム , $t=1$ とした DALO- $t$ と比較した . 図 13 と図 14 に，100 ノードから なる, 異なる密度のランダムグラフにおける解品質の比 較を示す. 図 13 の各評価関数の利得は, 関係する二変数 の值が同一の場合は利得を 0 とし，異なる場合は利得を 1 とした。また，図 14 は, 頂点彩色問題の利得に変化を 与え, 二变数値が異なる場合の利得を 1 から 9 の間でラ ンダムに選択した . 実験の結果，提案手法によって得ら れる解品質は, 既存の手法よりも高品質であることが分 かった . 图 13 と図 14 を比較すると，提案手法の効果に 差が出ているが，重みの値の範囲も考慮すると，同樣の 傾向であることが分かった．また，密度が上がるにつれ て , p-optimal アルゴリズムと DALO ，および提案手法 の解品質の差が大きくなることが分かった .これは，上 で述べたように，除去される後退辺の数が多くなるため である。

\section{4 収束までの実行サイクル数}

次に, $(p=1, t=1)$ とした提案手法と, $t=1$ とした DALO$t$ の収束速度を比較した .ここで，提案手法における $p$ optimal 解法の実行サイクル数を, (ノード数 -1$) \times 2$ と 見積り実験を行った．この実験では，部分木間に制約辺 が存在しないため，木幅を制限する処理は必要ない，実 行サイクル数は 500 で打ちきった .ノード数を 50 , 密度 4 のランダムグラフにおける収束速度の比較を图 15 に示 す. 実験の結果，提案手法よりも DALO- $t$ の方が早く収 束することが分かった .

\section{5 考察}

提案手法について実験結果をもとに考察する．

提案手法では, まず, $p$-optimality に基づく解法と同樣 の手法である，p-optimal 解法を実行する .これにより， 得られた利得は, 各エージェントを中心とする部分問題 については，次に実行する， $C$-optimal 解法の利得に置 き換わる. 乥れ以外の部分の利得は, $C$-optimal 解法の 利得に加算される. $C$-optimal 解法は, 適用する部分問 題の評価関数を全て評価するので, 产の結果, 提案手法 では, $p$-optimality に基づく解法と同等以上の利得が得 られると考えられる．次に， $C$-optimality に基づく解法 と同樣の手法である， $C$-optimal 解法を実行する .この
とき，元の $C$-optimality に基づく解法よりも，広範囲の 情報を利用して， $C$-optimal な解を得る，弚の結果，提 案手法は, 元の $C$-optimality に基づく解法と同等以上の 利得が得られると考えられる．

このような性質から，提案手法の下界値は, $p$-optimal アルゴリズム, DALO よりも, 高い下界值が得られると考 えられる.実験の結果，図 6 より，提案手法は, $p$-optimal アルゴリズム, DALO よりも高い下界値が得られること が分かった .すなわち, 実験結果は, 上記の性質を支持 しているといえる

図 8 から図 11 より，提案手法は，既存の手法よりも， 高品質な解か得られている.これは, 上記に示したように， 提案手法は, $p$-optimal 解法の実行, 光して, $C$-optimal 解法の実行時に, 局所情報に加えて, $p$-optimal 解法の実 行により，生成した UTIL メッセージも利用する．した がって，広範囲の情報に基づいて，局所範囲の最適な割 り当てを計算するため, 高品質な解が得られたと考えら れる。

ランダムグラフとスケールフリーグラフの各手法の解 品質の違いについて, 考察する. 実験の結果 , スケールフ リーグラフのほうが, 提案手法と既存の手法の解品質の差 が大きいことが分かった . スケールフリーグラフは, ハブ 構造を持つ，弚のため, DALO と提案手法の $C$-optimal 解法において，含まれるノード数が非常に多いグループ が存在する．弚のため, DALO でも十分な解品質が得ら れると考えられるが，提案手法では，光れに加えて，フ リンジが生成した UTIL メッセージも利用する．よって， ほとんど制約網全体の，大域的な情報を得ることができ たために , スケールフリーグラフのほうが , 提案手法と既 存の手法の解品質の差が大きくなったと考えられる . ま た， BA モデルによって生成したスケールフリーグラフ とランダムグラフは, 密度の増加とともに, サイクル数 が多くなる．したがって, 密度の増加に対する解品質の 変化に，同樣の傾向が見られたと考えられるが，より詳 細な比較は , 今後の課題とする

提案手法では, パラメータ $p, t / s$ を調整することによ り，計算および通信コストを犠牲にする代わりに，より 高品質な解を得ることができる .ここで, パラメータ $p$ ， $t / s$ の設定について考察する. $p$-optimal アルゴリズムの 解品質は，除去される制約辺に依存する . 問題のグラフ にサイクルが多く含まれる場合，すなわちグラフ密度が 大きい場合，除去される制約辺が多くなるため，解品質 が大きく低下する可能性がある．また，DALO の解品質 は, グループサイズに依存する . 問題のグラフ密度が小 さい場合 , グループサイズが小さくなるため, 解品質が 大きく低下する可能性がある . したがって , 問題のグラ フ密度が大きい場合，パラメータ $p$ を大きく, 問題のグ ラフ密度が小さい場合，パラメータ $t / s$ を大きく設定す ることで，解品質の低下を抑制できると考えられる．し かし，実際には，計算量や記憶量に制限があるため，可 
能な範囲でバランスをとることが重要である .

提案手法の収束速度は, $p$-optimal 解法の実行時間に依 存する. 本論文では, パラメータ $p=1$ とし, $p$-optimal 解 法の実行時間を最悪の場合を想定して $($ ノード数 -1$) \times 2$ と見積もつて実験を行った結果, 既存のDALOよりも収 束する時間が大きくなることが分かった .この問題につ いては，提案手法と DALO を多重実行する手法を用い る [飯塚 09] . すなわち，p-optimal 解法を実行している 間は，DALO を実行することで得られた解を採用するこ とで, この問題を隠蔽できると考えられる。

\section{7. ま と め}

本論文では, DCOP の非厳密解法によって得られる解 品質に着目し，異なる解の最適性の指標 $p$-optimality , $C$ optimality に基づく非厳密解法を統合する手法を提案し た.すなわち，p-optimalityに基づく解法を実行し，得 られた情報のもとで, $C$-optimality に基づく解法を実行 することにより，両者を相補的に用いる手法を提案した． 実験により提案手法の有効性を評価したところ，既存の $p$-optimal アルゴリズム, DALOよりも高品質な解が得 られることを示した .

今後の研究課題として, 提案手法を Bounded Max-sum 解法 [Rogers 11] を含む, 他の近似解法との比較が挙げ られる。また，応用問題に対して，提案手法の有効性を 検証する . 例えば, センサネットワーク [Zhang 05] 等の 応用問題に対して, 解品質, 計算, 通信コストを考慮に 入れて提案手法がどれだけ有効であるかを調べることが 考えられる .

謝辞 本研究の一部は, 科学研究費補助金 (基盤研究 (C)25330257), 平成 23 年度人工知能研究振興財団研究 助成による.

\section{$\diamond$ 参 考 文 献 $\diamond$}

[A.Farinelli 08] A.Farinelli, , A.Rogers, , A.Petcu, , and N.R.Jennings, : Decentralized Coordination of Low-Powered Embedded Devices Using the Max-Sum Algorithm, Autonomous Agents and Multiagent Systems, Vol. 2, pp. 639-646 (2008)

[Atlas 07] Atlas, J. and Decker, K.: A complete distributed constraint optimization method for non-traditional pseudotree arrangements, in Autonomous Agents and Multiagent Systems, pp. 111:1-111:8 (2007)

[Barabasi 99] Barabasi, A.-L. and Albert, R.: Emergence of Scaling in Random Networks, Science, Vol. 286, No. 5439, pp. 509-512 (1999)

[Bowring 08] Bowring, E., Pearce, J. P., Portway, C., Jain, M., and Tambe, M.: On K-optimal distributed constraint optimization algorithms: new bounds and algorithms, in Autonomous Agents and Multiagent Systems, pp. 607-614 (2008)

[Kiekintveld 10] Kiekintveld, C., Yin, Z., Kumar, A., and Tambe, M.: Asynchronous algorithms for approximate distributed constraint optimization with quality bounds, in Autonomous Agents and Multiagent Systems, pp. 133-140 (2010)

[Miller 12] Miller, S., Ramchurn, S. D., and Rogers, A.: Optimal decentralised dispatch of embedded generation in the smart grid, in $\mathrm{Au}$ tonomous Agents and Multiagent Systems, pp. 281-288 (2012)
[Modi 05] Modi, P. J., Shen, W.-M., Tambe, M., and Yokoo, M.: Adopt: asynchronous distributed constraint optimization with quality guarantees, Artificial Intelligence, Vol. 161, No. 1-2, pp. 149-180 (2005)

[Petcu 05] Petcu, A. and Faltings, B.: A scalable method for multiagent constraint optimization, in International Joint Conference on Artificial Intelligence, pp. 266-271 (2005)

[Ramchurn 10] Ramchurn, S. D., Farinelli, A., Macarthur, K. S., and Jennings, N. R.: Decentralized Coordination in RoboCup Rescue, Computer Journal, Vol. 53, No. 9, pp. 1447-1461 (2010)

[Rogers 11] Rogers, A., Farinelli, A., Stranders, R., and Jennings, N. R.: Bounded Approximate Decentralised Coordination via the Max-sum Algorithm, Artificial. Intelligence., Vol. 175, No. 2, pp. 730-759 (2011)

[Vinyals 11] Vinyals, M., Shieh, E., Cerquides, J., RodríguezAguilar, J. A., Yin, Z., Tambe, M., and Bowring, E.: Quality guarantees for region optimal DCOP algorithms, in Autonomous Agents and Multiagent Systems, pp. 133-140 (2011)

[Zhang 02] Zhang, W., Wang, O., and Wittenburg, L.: Distributed stochastic search for constraint satisfaction and optimization: Parallelism, phase transitions and performance, in Association for the Advancement of Artificial Intelligence Workshop on Probabilistic Approaches in Search, pp. 53-59 (2002)

[Zhang 05] Zhang, W., Wang, G., Xing, Z., and Wittenburg, L.: Distributed stochastic search and distributed breakout: properties, comparison and applications to constraint optimization problems in sensor networks, Artificial Intelligence, Vol. 161, No. 1-2, pp. 55-87 (2005)

[沖本 11] 沖本 天太, ジョヨンジュン, 岩崎敦, 横尾 真 : 擬似木に 基づく分散制約最適化問題の精度保証付き非厳密解法の提案, 情 報処理学会論文誌, Vol. 52, No. 12, pp. 3786-3795 (2011)

[飯塚 09] 飯塚 泰樹, 竹内 有陮: 分散制約最適化問題近似解法の多 重実行の効果, 情報処理学会論文誌, Vol. 50, No. 12, pp. 3136-3149 (2009)

〔担当委員 : 山下 倫央〕

2013 年 11 月 14 日 受理

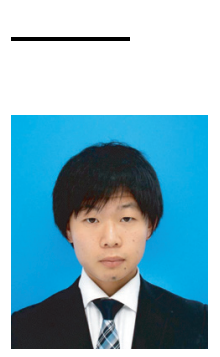

\section{者 紹}

谷藤 拓麻

2013 年名古屋工業大学工学部情報工学科卒業. 2013 年同 大学大学院博士前期課程在学中.マルチエージェント, 分散 協路問題解決等に興味を持つ。電子情報通信学会学生会員.

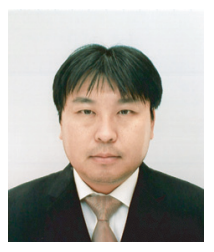

松井 俊浩(正会員)

1995 年名古屋工業大学電気情報工学科卒業. 1999 年同大 学大学院博士前期課程修了. 2006 年同博士後期課程修了。 同年名古屋工業大学情報基盤センター助手 . 2007 年同助 教. 2011 年同准教授、現在に至る.分散協調処理, マル チェージェントシステム, 分散制約最適化問題に関する研 究に従事. 博士 (工学). 情報処理学会, 電子情報通信学会, 各会員.

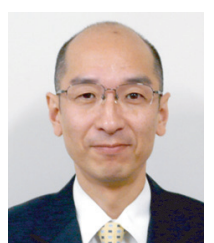

松尾 啓志(正会員)

1983 年名古屋工業大学情報工学科卒業. 1989 年同大学大 学院博士課程修了. 同年名古屋工業大学電気情報工学科助 手. 講師, 助教授を経て, 2003 年同大学院教授. 2006 年 情報基盤センターセンター長 (併任) . 現在に至る . 分散シ ステムに関する研究に従事. 工学博士 . 情報処理学会, 電 子情報通信学会, IEEE 各会員. 